\title{
Trzecie ciało
}

Marta Tomczok 


\section{Trzecie ciało}

Marta Tomczok

TEKSTY DRUGIE 2017, NR 6, S. 278-286

DOI: $10.18318 /$ td.2017.6.17

\section{Fala}

Książka Katarzyny Czeczot Ofelizm. Romantyczne zawłaszczenia, feministyczne interwencje pod wieloma względami przypomina falę. Płynna i wzbierająca jest przede wszystkim sama opowieść, zaczynająca się bardzo konkretnie, od zdefiniowania tytułowego pojęcia, zdającego się dotyczyć przede wszystkim literatury, zakończona jednak nieliteracko, refleksją nad ludzkim głosem, który okazuje się potworny i nieludzki. Z naturą fali wiąże się także tematyka tego opracowania: jest ono poświęcone przede wszystkim obrazom wody i ich związkom z roślinami i kobiecością. Ale są to obrazy ewoluujące, by nie rzec: falujące. Śledzimy ich dynamiczną naturę, dość prędko odrywającą się od szekspirowskiego podłoża, i jej kolejne metamorfozy, coraz bardziej bioróżnorodne i zwizualizowane. Jest to falowanie, w którym rozpoznać można ruch pewnej idei, na początku XIX wieku nazywanej związkiem kobiety z naturą; dzisiaj widzi się w niej co najmniej tego związku dekonstrukcję. I to dekonstrukcję, która jak fala podmywa pierwotne obrazy

Marta Tomczok pracuje w Instytucie Nauk o Literaturze Polskiej UŚ. Opublikowała m.in. Metonimie Zagłady. O literaturze polskiej 1987-2012 (Katowice 2013). Zajmuje się najnowszymi narracjami o Zagładzie, popkulturą i jej wpływem na społeczny odbiór Zagłady oraz jej związkami z postmodernizmem. Redaktor naczelna rocznika naukowego „Narracje o Zagładzie". Kontakt: martacuber@interia.pl 
i bezpowrotnie wypłukuje ich kulturową szkodliwość, ujawniając wartość dodaną. Czyni to jednak za pomocą tylu różnych składników, że nie sposób widzieć w nich wyłącznie literackiego rodowodu. Dlatego słowo "falowy” w przypadku Ofelizmu... może oznaczać zarówno niewinnie rozpoczynającą się narrację, która przybiera postać dramatycznego rozpoznania związanego $\mathrm{z}$ antropocenem, jak i ruchomą ramę modalną, w której autorka zawarła wypowiedzi na temat pomysłowo zebranego materiału: romantycznych ballad, nowofalowych (znowu fala!) filmów, instalacji i performansów, ale i opery narodowej. Z jednej strony Ofelizm... to przenikliwe, literaturoznawcze studium pewnego wizualnego kodu (lecz nie pojęcia, jak zastrzega autorka'), które intrygująco wykracza poza swoją dyscyplinę. Z drugiej, co chyba ważniejsze, jest to opracowanie, po które sięgać będą nie tylko historycy literatury XIX wieku, ale także czytelnicy zainteresowani filmem, ekofeminizmem, sztuką, prozą Sylvii Plath, a przede wszystkim historią pewnego obrazu, raz po raz wracającego $\mathrm{w}$ różnych odmianach i odsłonach: kobiety na tle wody i roślin. W tym ostatnim znaczeniu w zasadzie każda autorefleksyjna czytelniczka, szukająca zrozumienia dla własnych relacji z tożsamością, śmiercią czy seksualnością może nazywać siebie podmiotem Ofelizmu.... Warto dodać, że i słowo „podmiot" ma u Czeczot falową naturę. Od początku wywodu oznacza bowiem nie tyle kobiety, ile nadmiar kobiecości, dający się zrozumieć jako szaleństwo, ale i praktyki drag².

Falująca woda może stać się ogromną i bardzo twórczą (bądź niszczycielską) falą, ale równie prawdopodobne jest, że wyczerpie swoją energię w jednej chwili, w nieokreślony sposób. Takie jest zakończenie Ofelizmu..., a właściwie brak zakończenia. Narracja „urywa się" bowiem w dość nieoczekiwanym momencie.

\section{Pojęcie}

Definicję ofelizmu otrzymujemy już w drugim zdaniu książki. Brzmi ona następująco: „Tematem jest tu pewien wizualny kod - obecny w tych wyobrażeniach i przez nie utrwalony - który z czasem powędrował w rejony niekiedy bardzo odległe od tematu Szekspira. Obrazy ofeliczne można wstępnie zdefiniować jako wizerunki ciała młodej, pięknej kobiety w otoczeniu kwiatów

\footnotetext{
1 K. Czeczot Ofelizm. Romantyczne zawłaszczenia, feministyczne interwencje, Wydawnictwo IBL PAN, Warszawa 2016, s. 13.

2 Tamże, s. 68-69.
} 
i/lub wody, funkcjonujące w kulturze Zachodu jako przedstawienia deszyfrujące zagadkę kobiecości. Ofelizm nie jest więc pojęciem analogicznym do hamletyzmu, oznaczającego pewną postawę życiową; w pierwszej kolejności bowiem odnosi się on do sfery wizualnej"3.

Czeczot bada zatem niezwykle szerokie imaginarium, żywiące się - jak wspomniałam - kobiecością, roślinami i wodą. Metafora bioorganiczna jest tu jak najbardziej na miejscu, ponieważ owo imaginarium pozostaje w ciągłym ruchu, składa się na nie bowiem konstelacja inspirowanych postacią Szekspirowskiej Ofelii różnorakich obrazów, którym autorka nadaje wspólną postać Nachleben. W tym wywiedzionym z pism Aby Warburga terminie, oznaczającym „po-życie”, „życie po życiu” bądź „przejście na inny etap, bez akcentowania zerwania ani tym bardziej śmierci"“4, Czeczot utrwala romantyczne „długie trwanie”, które rozumie jednak inaczej niż autorka Życia pośmiertnego Konrada Wallenroda, Maria Janion. W nowym ujęciu ma ono postać Benjaminowskiej konstelacji ${ }^{5}$, złożonej z elementów niekiedy bardzo od siebie odległych, które jednak jako całość nadają kształt pewnej idei, w inny sposób nieosiągalnej. Może właśnie dlatego autorka mimo prędko zbudowanej i bardzo precyzyjnej definicji ofelizmu - co w polskich opracowaniach humanistycznych zdarza się rzadko - do zrozumienia zjawiska potrzebuje przede wszystkim pracy przykładów. Nie osłabiają one wprawdzie zaproponowanego we Wstępie tytułowego kodu, ale pozwalają lepiej wytłumaczyć, co Czeczot ma na myśli, pisząc: „przedmiotem moich rozważań nie jest ani pierwsze, ani drugie ciało Ofelii [...]. Tym, co mnie interesuje, jest trzecie ciało Ofelii, ciało nawiedzane przez widmo szekspirowskiej bohaterki, ale przynależące do zupełnie innego porządku i wytwarzające całkowicie nowe sensy"6. „Trzecie ciało", trochę jak trzecia fala feminizmu, oznacza wywrotowość zapisaną w ofelicznych obrazach, ich przełomowość, rewolucyjność, siłę, polityczność i kreatywność, ale i widmowość, powracającą falowo w coraz odleglejszych skojarzeniach. Nie oznacza natomiast umocowanej w patriarchalizmie melancholii czy romantycznej nekroestetyki.

3 Tamże, s. 13.

4 A. Warburg Atlas obrazów Mnemosyne, red. M. Warnke przy współpracy C. Brink, red. nauk. wyd. pol. i przeł. P. Brożyński, M. Jędrzejczyk, Narodowe Centrum Kultury, Warszawa 2015, s. XXIV.

5 Por. A. Lipszyc Przedmowa: Wyjście Benjamina, w: W. Benjamin Konstelacje. Wybór tekstów, przeł. A. Lipszyc, A. Wołkowicz, Wydawnictwo Uniwersytetu Jagiellońskiego, Kraków 2012, s. IX.

6 K. Czeczot Ofelizm..., s. 34 . 


\section{Metoda}

Słowem-kluczem do zrozumienia koncepcji Czeczot wydaje się wspomniana konstelacyjność. Tłumaczy ona, nieprzystający do zaproponowanego we Wstępie sztywnego porządku, pewien artystyczno-hermeneutyczny „nieład”, wynikający z faktu, że Ofelizm... nie jest historią tytułowego pojęcia (czy raczej kodu), nie jest też systematyką jego słowno-wizualnych ujęć; tworzy raczej Warburgowski atlas pamięci i swobodny układ obrazów. Trochę tak, jakby autorce zabrakło chęci do napisania obszernej, pracochłonnej opowieści, która byłaby kwintesencją wyobrażeń na temat związków ludzi ze światem roślin i wody. Częściowo wyjaśnia tę sytuację fragment Podziękowań, z którego wynika, że pomysł na Ofelizm... zrodził się podczas pracy nad rozprawą doktorską poświęconą figurom szaleństwa w polskiej literaturze romantycznej’. Najnowsza książka Czeczot to zatem tyleż odprysk z akademickiej roboty, co jej dekonstrukcja, oparta na przeświadczeniu o przewadze indywidualnych wyborów, podyktowanych swobodnym, antologijnym układem treści nad tworzeniem zamkniętych szczelnie opracowań.

Ofelizm... to także książka o samobójstwach kobiet: tajemniczych, bezkrwawych, skrytych, estetycznych i oddziałujących na wyobraźnię. Tego podstawowego wymiaru obrazu ofelicznego, o którym pisze w Wyobraźni poetyckiej Gaston Bachelard ${ }^{8}$, Czeczot nie wspomina, co czyni z jej monografii... rzecz o ukrywaniu wspomnianej skrytości, o wycofaniu się z ujawniania tajemnicy. Uwagę autorki zwracają dopiero przemiany, jakie następują w imaginarium ofelicznym w drugiej połowie XX wieku. Staje się ono wówczas „polem interwencji, które można określić jako feministyczne". Nie jest to jednak dostatecznie jasny wybór. Bachelard jako jeden z pierwszych podjął studia nad wyobraźnią ludzi i żywiołami przyrody. Wprowadził także do badań kategorię „kompleksu Ofelii”, oznaczającą „ powołanie” kobiety do śmierci w wodzie, dającej początek niekończącym się, męskim, melancholijnym i kojącym marzeniom, zamykającym kobiecość w pułapce nekroestetyki ${ }^{10}$. Czeczot reprezentuje odległy biegun myślenia o kobiecości, oparty przede wszystkim na podważaniu wyobrażeń bliskich Bachelardowi. Szkoda, że zamiast sięgnąć

7 Tamże, s. 332.

8 Por. G. Bachelard Wyobraźnia poetycka. Wybór pism, wybór H. Chudak, przeł. H. Chudak, A. Tatarkiewicz, PIW, Warszawa 1975.

9 K. Czeczot Ofelizm..., s. 34.

G. Bachelard Wyobraźnia poetycka ..., s. 154-155. 
do jego pism i zrekonstruować ich, uderzającą miejscami, anachroniczność, autorka pomija Wyobraźnię poetycką. A przecież można w niej znaleźć i takie, zastanawiająco aktualne fragmenty: „Niepodobna wokół jednego wątku zgromadzić różniejszych obrazów. Fakt, że wypada uznać ich jedność, fakt, że imię Ofelii powraca pod piórem w najbardziej różnorodnych okolicznościach - dowodzi dobitnie, że imię to stanowi symbol wielkiego prawa rządzącego wyobraźnią"11.

Ów brak myśli Bachelarda jako negatywnej tradycji wydaje mi się tym bardziej uderzający, że to właśnie ona, niestety w pozytywnym znaczeniu, stanowiła przez lata źródło inspiracji dla polskich studiów akwatycznych ${ }^{12}$, które nawet wówczas, gdy przeważał w nich komponent feministyczny, oscylowały wokół romantycznych i mizoginicznych symboli³ ${ }^{13}$. Autorka próbuje ów brak wytłumaczyć, sygnalizując szkodliwość nekroestetyki i przypominając ważną w tym kontekście książkę Elizabeth Bronfen Over Her Dead Body. Death, Feminity and the Aestehetic. Nie wynika stąd jednak - także niejasne w perspektywie książki - zróżnicowanie obrazów ofelicznych wytwarzanych i kontrolowanych przez sztukę męską. W sposób oczywisty różnią się między sobą dwa filmy analizowane przez Czeczot: Historia Adèle $H^{14}$. Françoisa Truffauta i Valentino Kena Russella. Z jednej strony mamy męskie kino, gdzie dominuje potrzeba zapanowania nad kobiecym dziełem i ciałem, z drugiej kobiecość symbolizującą przebranie i pożądanie oraz walkę o władzę i media. Dyskusyjne - przynamniej częściowo - są jednak, przyjmowane przez

Tamże, s. 163.

Dość przypomnieć w tym miejscu studia nad wyobraźnią poetycką Aleksandra Nawareckiego czy Leszka Zwierzyńskiego. Por. A. Nawarecki Czarny karnawał: „Uwagi o śmierci niechybnej” księdza Baki: poetyka tekstu i paradoksy recepcji, Zakład Narodowy im. Ossolińskich, WrocławWarszawa-Kraków 1991; A. Nawarecki Rzeczy i marzenia. Studia o wyobraźni poetyckiej skamandrytów, Wydawnictwo Naukowe Śląsk, Katowice 1993; L. Zwierzyński Wyobraźnia akwatyczna Mickiewicza, Wydawnictwo Uniwersytetu Śląskiego, Katowice 1998.

13 Myślę tu przede wszystkim o własnej przygodzie z lekturą prozy Leo Lipskiego, w której szczególne miejsce zajmuje powieść Niespokojni, będąca zapisem imaginarium poholokaustowego, po brzegi - by tak się wyrazić - wypełnionego wodą. Główna bohaterka Niespokojnych, Ewa, tonie. Obraz ten wielokrotnie powraca w powieści w różnych konfiguracjach, raczej stabilizujących melancholijną, męską wyobraźnię niż ją analizujących czy weryfikujących. Być może wejście przez Czeczot w dialog z Bachelardem pozwoliłoby autorom istniejących już studiów nad wyobraźnią na ponowne przemyślenie znaczenia marzenia o wodzie, towarzyszącego kobiecemu podmiotowi. Zob. M. Cuber Trofea wyobraźni: o prozie Leo Lipskiego, Wydawnictwo Uniwersytetu Śląskiego, Katowice 2011.

14 Takim tytułem posługuje się Katarzyna Czeczot. Polski tytuł brzmi: Miłość Adeli H. 
autorkę $\mathrm{z}$ dystansem, ale i pominięciem ważnego w tym przypadku kontekstu, nekroestetyczne refleksje Stefana Chwina. W Ofelizmie... występuje on przede wszystkim jako komentator filmu Truffauta ${ }^{15}$. Nie należy zapominać, że Chwin jako prozaik jest przede wszystkim autorem niemałego katalogu efektownych obrazów kobiecej śmierci i chorób, z kąpielami w wannie i utonięciem bohaterki Hanemanna na czele. W jego Samobójstwie jako doświadczeniu wyobraźni śmierć Ofelii przedstawiona przez Johna Everetta Millaisa, o której Czeczot programowo nie pisze, urasta do rangi „pięknej śmierci” i zwycięstwa człowieka $\mathrm{z}$ „upokarzającymi zależnościami od bezwzględnych praw natury"16. Pominięcie negatywnej tradycji obrazów ofelicznych wymagałoby opisania przez autorkę tzw. pierwszego i drugiego ciała Ofelii, a zatem zebrania materiału na osobną książkę. Ów brak, jak starałam się pokazać, bywa wprawdzie zastanawiający, ale nie rzutuje zasadniczo na przenikliwość omawianego opracowania.

\section{Materiał}

Obrazów ofelicznych - pisał Bachelard - jest tak wiele, że tworzą one jeden z filarów ludzkiej wyobraźni. Książka Czeczot nie oddaje tego bogactwa; nie stara się również stworzyć wrażenia, że jest czymś innym niż konkretnym wyborem spośród długiej listy możliwości. Nie ma w niej przede wszystkim głębszego namysłu nad samą Ofelią i jej wizerunkami, chociażby we wspomnianej twórczości Millaisa. Uwagi o modelce Elizabeth Siddall pojawiają się okazjonalnie. Autorka nie pisze o filmie Hamlet Kennetha Branagha, Fortepianie Jane Campion czy Romeo i Julii Baza Luhrmanna (sceny z akwarium). Nie wspomina też o Śmierci w wodzie z Ziemi jałowej Thomasa Stearnsa Eliota i wielu innych przykładach obrazów ofelicznych w literaturze współczesnej (od Chwina po Martę Masadę). Proponuje za to lekturę tekstów romantycznych, od Rybki Mickiewicza po Ulane Józefa Ignacego Kraszewskiego, powieści dwudziestowiecznych (jak Szklany klosz Plath) i sztuk wizualnych z naciskiem na widowiska. Należą do nich: najstarsze inscenizacje Dziadów, Halka Stanisława Moniuszki, instalacje Teresy Murak, opery podwodne Julianny Snapper oraz wspomniane filmy Truffauta i Russella. Osobną kategorię tworzy siedemdziesiąt sześć ilustracji (czyli jedna czwarta książki!), stanowiących bogaty

15 S. Chwin Kompleks Leopoldyny, w: Odmieńcy, wybór, oprac. i red. M. Janion, Z. Majchrowski, Wydawnictwo Morskie, Gdańsk 1982. 
kontekst dla rozważań autorki, a zarazem dyskretną, choć przecież bardzo barwną odpowiedź na słowa Bachelarda o znaczeniu obrazów ofelicznych dla wyobraźni. Znalazły się wśród nich kadry z nieomawianych przez Czeczot filmów (np. Melancholii Larsa von Triera, At Land Mai Deren, Bonheur Agnès Vardy, Stokrotki Věry Chytilovej, Brzeziny Andrzeja Wajdy, Godziny Stephana Daldry'ego, American Beauty Sama Mendersa, Przekleństwa niewinności Sofii Coppoli, Piekło Dantego Kena Russella), zdjęcia dawnych, teatralnych kostiumów Ofelii do inscenizacji, fotografie pacjentów szpitali psychiatrycznych, obrazy Flory, pocztówki z podobiznami rusałek i boginek leśnych, obrazy syren (z filmu Johna Duigana i malarstwa Teofila Kwiatkowskiego), a nawet zdjęcia Wacława Niżyńskiego. Wszystko to sprawia, że książka Czeczot nie może być czytana jedynie w kategoriach klasycznej monografii akademickiej, od której oczekuje się chronologicznego układu, zobiektywizowanego wywodu, jasnych wniosków i konkretnego przesłania. Mamy do czynienia z innowacyjnym, otwartym i interdyscyplinarnym opracowaniem, w którym narracja wizualna odgrywa równorzędną rolę wobec narracji werbalnej (choć może wydawać się ona cichsza, a przez to bardziej dyskretna). Jaki jednak - oprócz dekonstrukcyjnego - jest jej potencjał? Można by rzec: trójwymiarowy; polityczny, autobiograficzny i ekokrytyczny. Pierwszy odnosi się przede wszystkim do opowieści o chłopkach, takich jak Halka czy Ulana, gdzie dominuje wątek klasowej i płciowej nierówności, wyostrzony w obrazach uwiedzenia, porzucenia i samobójstwa. Oglądając Halkę w kontekście uwag Chwina z Samobójstwa jako doświadczenia wyobraźni, wyraźnie widzimy, jak ważną rolę odgrywa w krytyce tych wizualizacji myśl lewicowa i do czego doprowadził jej brak (uwagi Bachelarda o akwatycznej naturze kobiet i łagodnej śmierci w wodzie).„Obłęd - pisze Czeczot - jakiego doświadcza wraz z miłosnym zawodem chłopka, staje się najbardziej sugestywną formą jej odpodmiotowienia"17. Jednak to nie powieść Kraszewskiego czy opera Moniuszki, lecz wydany w 1840 roku „obraz dramatyczny” Kazimierza Władysława Wójcickiego Góralka, uchodzący za pierwowzór Halki, byłby narracją najbardziej wywrotową. Podobnie jak niektóre ballady Mickiewicza, takie jak Rybka czy Świtezianka, pokazujące na przykładzie relacji rusałek nie - jak uważano dotąd - mściwość kobiet, lecz ich siostrzaństwo. W zupełnie innym świetle ideę siostry (a właściwie jej widmo) wciela córka Victora Hugo i bohaterka studiów nad „odmieńcami” Marii Janion, Adèle H. Przedwczesna śmierć Leopoldyny czyni z niej osobę opętaną miłością i zazdrosną. Czeczot

17 K. Czeczot Ofelizm..., s. 101. 
przygląda się jednak przede wszystkim dotąd pomijanej sferze życia Adeli, czyli jej pisarstwu (Adèle Hugo prowadziła dzienniki). Odkrywa w nim podmiotowy, autobiograficzno-polityczny potencjał, przez Truffauta pokazany jako walka bohaterki z mężczyznami, a zwłaszcza z kochankiem i ojcem. Francuski film i omówiona w kolejnym rozdziale powieść Plath stanowią dwie najważniejsze wypowiedzi Czeczot, z których płynie najwięcej wniosków dla zrozumienia wielowiekowego okrucieństwa wobec kobiet zawierającego się w pojęciu ofelizmu. Jego koniec połączony z refleksją nad rosnącą siłą kobiecości i sprawczością roślin pokazuje autorka przede wszystkim w analizach oper Snapper i instalacji Murak. Jest to dobry moment, żeby przyjrzeć się, na czym polegała XIX-wieczna fascynacja sztucznym pięknem, widoczna przede wszystkim w Inteligencji kwiatów Maurycego Maeterlincka, i ile się w niej zachowało we współczesnych narracjach postapokaliptycznych, do jakich należą praca Dougala Dixona Man After Man. An Anthropology of The Future wraz z koncepcją wodnego człowieka (aquamorpha) czy, inspirowane nią, wspomniane widowiska podwodne. W tych ostatnich woda nie jest już miejscem zniknięcia kobiety, lecz medium, dzięki któremu możemy pojąć krzyki bólu i język okrucieństwa, wypełniające sztukę, ale także zrozumieć, że niekoniecznie „człowiek jest częścią środowiska”, lecz że „środowisko jest częścią człowieka”, a „ludzki głos nigdy nie był wyłącznie ludzki"18.

Ofelizm... Katarzyny Czeczot wytycza kierunek, w jakim może zmierzać humanistyka, dokonująca rewindykacji literatury poprzednich stuleci. Po pierwsze, nie powinno w niej zabraknąć perspektywy ogólnej, obejmującej różnorodny materiał analityczny. Po drugie, narracja antologijna może się okazać równie trafnym wyborem systematyzacji wiedzy, co narracja kronikarska, prowadząca do syntezy wiedzy i zamknięcia jej wyraźną konkluzją. Po trzecie wreszcie, w Ofelizmie... czytelnik odnajdzie znakomity dowód twórczej kontynuacji badań, prowadzonych od czasów kolokwiów gdańskich przez Marię Janion i jej zespół (wiele zaproponowanych wtedy tematów, jak ballady romantyczne czy Historia Adéle H., Czeczot zresztą podejmuje). 


\section{Abstract}

\section{Marta Tomczok}

UNIVERSITY OF SILESIA IN KATOWICE

The Third Body

Review: Katarzyna Czeczot, Ofelizm: Romantyczne zawłaszczenia, feministyczne interwencje [Ophelism: Romantic Reappropriations, Feminist Interventions], Wydawnictwo IBL, Warsaw 2016, 332 pp.

\section{Keywords}

femininity, water, ophelism, ecocriticism, history of ideas, the nineteenth century 